\title{
IMPACTS STUDY OF METHYLAMINE AVERMECTIN AS A NEW BIOINSECTICIDE AGAINST THE COTTON LEAFWORM Spodoptera littoralis (Boisd.) AND MALE ALBINO RATS
}

\author{
SALLAM, A. M. ${ }^{1}$, M. E. ELNAGGAR ${ }^{2}$, H. F. DAHI ${ }^{2}$, DOAA A. ALI ${ }^{1}$ \\ and HEBA A. WARDA ${ }^{2}$
}

1. Faculty of Science, Mansoura University

2. Plant Protection Research Institute, ARC, Dokki, Giza

(Manuscript received 20 December 2010)

\begin{abstract}
The efficacy of a new semi-synthetic avermectin derivative Methylamine avermectin (Radical $0.5 \%$ EC) was evaluated on the larvae of the Egyptian cotton leafworm, Spodoptera littoralis (Boisd): (Lepidoptera: Noctuidae). The $2^{\text {nd }}$ instar larvae was more sensitive than $4^{\text {th }}$ instar larvae, the determined $L_{50}$ for $2^{\text {nd }}$ instar larvae was $0.021 \mathrm{ppm}$. From the obtained results it was clear that the larval duration, pupal duration, pupal weight, pupation percentage, adult emergence and the number of laid eggs of the $2^{\text {nd }}$ instar larvae treated with the $\mathrm{LC}_{50}$ of methylamine avermectin were decreased significantly compared to their control. While, male and female longevity insignificantly affected compared to control. On the other hand, male albino rats were administered oral doses equivalent to $1 / 10$ or $1 / 40$ of the $L_{50}$ value $(45 \mathrm{mg} / \mathrm{kg}$ body weight) for 21 days (day after day), since, methylamine avermectin affect on the biochemical parameters of liver function (i.e. aspartate aminotransferase activity, alanine amino transferase activity, albumin, cholesterol and triglycerides levels), kidney function (urea and creatinine concentration), testes function (testosterone).

Key words : Methylamine avermectin, Radical ${ }^{\circledR} 0.5 \%$ EC, Streptomyces avermactitis, Spodoptera littoralis, albino rats, toxicological, biological and biochemical study.
\end{abstract}

\section{INTRODUCTION}

In Egyptian cotton fields, the cotton leafworm, Spodoptera littoralis (Boisd.) and the lesser cotton leafworm (Beet armyworm) Spodoptera exigua Hbn. are among the most serious defoliators threaten the crop. Also, the cotton boll worms, the pink bollworm, Pectinophora gossypiella Saunders and the spiny bollworm, Earias insulana Boisd. cause the greatest part of cotton yield losses (Amin et. al., 2001).

Methylamine avermactine (Radical) is a novel semi-synthetic derivative of natural product abamactin in avermactin family. Abamactins (Avermactin B1) are a fermentation product from the soil microorganisms, Streptomyces avermactitis (Burg et. al., 1979). This materials act by interfering with the action of gamma aminobutyric 
acid (GABA) (Fritz et. al., 1979). It blocks post-synaptic potentials of neuromuscular juncations, leading to paralysis.

The present study aims to evaluate the side effects of methylamine avermectin on the toxicological and biological aspects on Spodoptera littoralis. And some hepatic and renal parameters in liver, kidney and testes of white albino rats.

\section{MATERIALS AND METHODS}

Bioinsecticide used: The used insecticide Radical 0.5\%EC, common name Methylamine Avermactin " 4-deoxy-4 (Methylamine)-(4 R) Avermactin Benzoate (salt)".

Tested insects:- The stock culture of susceptible Egyptian cotton leafworm Spodoptera littoralis was reaered on castor leaves (Ricinus communis L.) for several generations at laboratory conditions of $27 \pm 1{ }^{\circ} \mathrm{C}$ and $70 \pm 5 \%$ RH. (El Defrawi et. al., 1964).

\section{Bioassay}

Different concentrations of the insecticide were prepared. For each concentration, leaves of caster bean were washed, dried and immersed in tested solution for 30 seconds, then allowed to dry under laboratory conditions. Five replicates were made, 10 larvae for each replicate. The same number of replicates and larvae were considered as a control, these larvae were offered castor leaves immersed in distilled water. After feeding period of 24 hours on treated leaves, the percentage of mortality was recorded. The data were subjected to propit analysis (Klaassen and Eaton, 2001) for determining the $\mathrm{LC}_{50}$ value of the tested compound.

\section{Biological studies}

Larvae which treated with $\mathrm{LC}_{50}$ of the tested compounds were examined daily to determine the different biological aspects such as larval and pupal duration, pupal weight, and percentage of pupation and adult emergence, sex ratio and adult longevity.

\section{Tested animals and dosing}

Male albino rats (Rattus norvegicus var. albus), of 100 - $120 \mathrm{~g}$ were obtained from Helwan Farm, Cairo, Egypt the animals were acclimatized under laboratory conditions for one week. Food and water were provided adlibitum. Rats (7 rats/each dose) were given for 21 days (day after day) oral doses equaled to $4.5 \mathrm{mg} \mathrm{kg}-1$ b.w. 
(1/10 LD $\left.{ }_{50}\right)$ and $1.125 \mathrm{mg} \mathrm{kg}-1$ b.w. $\left(1 / 40 L D_{50}\right)$. Rats of control group were given water throughout the experimental time.

\section{Blood Samples}

At the end of this experiment (21 days), blood samples were individually collected from each rat, immediately after slaughtering in dry clean centrifuge tubes. and then centrifuged at 3000 r.p.m for 15 minutes, the supernated serum samples were drown in dry clean-capped tubes and kept in deep freezer a $\mathrm{t}-20 \mathrm{oC}$ until conducting the biochemical analysis.

\section{Biochemical Analysis}

Serum aminotransaminases, Serum albumin, Serum cholesterol, Serum triglycerides were measured as indicators for liver function, serum creatinine and urea levels were measured as indicators for kidney functions and testesteron hormone level measured as indicator for testes.

\section{Statistical Analysis}

Probit analysis was determined to calculate LC $_{50}$ (Finney, 1971), through software computer program. Statistical significant differences between individual means were determined by t- test.

\section{RESULTS AND DISCUSSION}

\section{Lethal effect of methylamine avermectin against the $2^{\text {nd }}$ instar larvae of $\boldsymbol{S}$. littoralis}

Data presented in Table (1) revealed that the lethal effect of methylamine avermectin increased by increasing the used concentration, these results were confirmed by those reported by Abdel Rahman et al. (2008) found that radical was most toxic against the $2^{\text {nd }}$ instar larvae of both laboratory and field strains. Also, Dahi et al. (2009) who mentioned that Radical bioassay under laboratory was effective against $S$. littoralis. The $2^{\text {nd }}$ instar larvae were more sensitive to the bioinsecticide than $4^{\text {th }}$ instar. Thus, the bioinsecticide Radical showed some promise for the control of this serious pest. 
Table 1. Lethal concentration values of Methylamine avermectin against $2^{\text {nd }}$ instar larvae of $S$. littoralis under laboratory conditions.

\begin{tabular}{|c|c|c|c|c|}
\hline \multirow{3}{*}{ Treatment } & Concentration (ppm) & Mortality \% & $\begin{array}{c}\text { LC50 } \\
\text { (ppm) }\end{array}$ & Slope \\
\hline \multirow{3}{*}{$\begin{array}{c}\text { Methylamine } \\
\text { avermectin }\end{array}$} & 0.156 & 100.0 & \\
\cline { 2 - 3 } & 0.078 & 66.7 & \\
\cline { 2 - 3 } & 0.019 & 26.7 & \multirow{2}{*}{0.021} & 3.35 \\
\cline { 2 - 3 } & 0.01 & 13.3 & \\
\hline Control & 0.005 & 6.7 & & \\
\hline
\end{tabular}

Latent effect of methylamine avermectin $\mathbf{L C}_{50}$ on $\mathbf{S}$. littoralis pre treated as $2^{\text {nd }}$ instar larvae

Regarding the effect of methylamine avermectin on the $2^{\text {nd }}$ instar larvae of $S$. littoralis after treatment with the $\mathrm{LC}_{50}$ concentration, data presented in Table (2) demonstrated that methylamine avermectin leads to a slight significant decrease in larval duration between the treatment and the control. While there was a high significant decrease in pupation percentages, mean pupal weight, mean pupal duration, between treatment and control. Finally there were a nonsignificant decrease in male and female longevity and a significant decrease in fecundity between treatments and control.

Our results in coincidence with Abdel Rahman et al. (2008) who reported that the treatment of the $2^{\text {nd }}$ instar larvae with methylamine avermectin gave highly significant reduction in pupation percentage, significant decrease in pupal weight and reduced the adult emergence percentage compared to the untreated larvae. 
Table 2. Effect of $\mathrm{LC}_{50}$ of methylamine avermectin on the adult stage of S. littoralis (Boisd.) pre treated as 2nd instar larvae.

\begin{tabular}{|c|c|c|c|}
\hline \multicolumn{2}{|l|}{ Biological Aspects } & Methylamine Avermectin & Control \\
\hline \multicolumn{2}{|c|}{ Larval duration (days \pm S.E ) } & $13.48 \pm 0.38^{*}$ & $14.86 \pm 0.07$ \\
\hline \multicolumn{2}{|l|}{ Larval mortality \% } & 38 & 4 \\
\hline \multicolumn{2}{|l|}{ Pupation \% } & 62 & 96 \\
\hline \multicolumn{2}{|c|}{ Mean Pupal weight (gm) } & $0.2510 \pm 0.008^{* * *}$ & $0.3497 \pm 0.005$ \\
\hline \multicolumn{2}{|c|}{ Mean Pupal duration ( days \pm S.E ) } & $9.36 \pm 0.2^{* * *}$ & $10.94 \pm 0.19$ \\
\hline \multicolumn{2}{|l|}{ Pupal mortality\% } & 19.4 & 6 \\
\hline \multicolumn{2}{|l|}{ Emergence \% } & 80.6 & 94 \\
\hline \multirow{2}{*}{ Sex ratio\% } & $0^{\pi}$ & 32 & 42.55 \\
\hline & q & 68 & 57.45 \\
\hline \multirow{2}{*}{ Longevity ( days \pm S.E ) } & 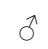 & $11.17 \pm 0.45^{\mathrm{ns}}$ & $12.1 \pm 0.86$ \\
\hline & 우 & $10.96 \pm 0.66^{\mathrm{ns}}$ & $11.44 \pm 1.04$ \\
\hline \multicolumn{2}{|c|}{ Fecundity ( No. of egg / female) } & $946 \pm 34.65^{* *}$ & $1263.23 \pm 71.34$ \\
\hline
\end{tabular}

\section{Effect of methylamine avermectin on liver function parameters}

Liver is often the primary target for the toxic effects of xenobiotics. It is known that the detoxification of the toxic materials which enter the body occurs mainly in the liver (Balistreri and Shaw, 1987). Therefore, liver can be used as an index for the toxicity of xenobiotics. Hence, the activities of some enzymes and levels of certain biochemical parameters representing liver function, i.e. AST, ALT, albumin, triglycerides and

Cholesterol was determined in treated and untreated rats. Data recorded in Table (3) showed a significant increase in the activity of AST, cholesterol and triglycerides while, ALT and albumin activities increased

significantly in serum of treated rats compared with the control group. The above results were in harmony with Abed El-Hamid and Refaie (2009) who found that Avermectin toxicity resulted in a nonsignificant increase in the activity of ALT. (Hsu et. al., 2001) reported that AST was elevated in abamectin dosed rats in a dose dependent manner. AST and ALT are considered to be sensitive indicators of hepatocellular damage and within limits can provide a quantitative assessment of the degree of damage sustained by the liver (Peng et. al., 2007). Elevation of AST, a cytosolic enzyme of the hepatocytes, reflects the increase of plasma membrane permeability resulting from the damage of hepatocytes (Plaa and Hewitt, 1982). 
Soliman et al. (2009) recorded that, Serum AST and ALT activities were increased significantly at Subacute oral toxicity and Subchronic oral Toxicity compared with control. Arise and Malomo (2009) they found that ivermectin led to significant increase $(P<0.05)$ in serum cholesterol concentrations, while albumin was significantly reduced $(P<0.05)$. These observations may be suggestive of deranged membrane structures and functions. Abed El-Hamid and Refaie (2009) found that Avermectin toxicity resulted in significant increase in total cholesterol levels. On the contrary, avermectin intoxication caused significant inhibition in the level of albumin.

Table 3. Serum aminotransferases activities (IU/ml), Serum Albumin ( $\mathrm{g} / \mathrm{dl})$, Cholesterol and Triglycerides level $(\mathrm{mg} / \mathrm{dl})$ of male albino rats as aresult of methylamine avermectin treatment.

\begin{tabular}{|c|c|c|c|c|c|c|c|c|c|c|}
\hline \multirow{2}{*}{ Treatment } & \multicolumn{2}{|c|}{ AST } & \multicolumn{2}{|c|}{ ALT } & \multicolumn{2}{|c|}{ Albumin } & \multicolumn{2}{|c|}{ Cholesterol } & \multicolumn{2}{|c|}{ Triglycerides } \\
\hline & activity & $\begin{array}{c}\% \text { of } \\
\text { change }\end{array}$ & activity & $\begin{array}{c}\% \text { of } \\
\text { change }\end{array}$ & activity & $\begin{array}{c}\% \text { of } \\
\text { change }\end{array}$ & activity & $\begin{array}{c}\% \text { of } \\
\text { change }\end{array}$ & activity & $\begin{array}{c}\% \text { of } \\
\text { change }\end{array}$ \\
\hline $\begin{array}{c}1 / 10 \mathrm{LD}_{50} \\
\text { methylamine } \\
\text { avermectin }\end{array}$ & \multicolumn{10}{|c|}{ All tested rats died after 10 days of the experiment duration. } \\
\hline $\begin{array}{c}1 / 40 \mathrm{LD}_{50} \\
\text { methylamine } \\
\text { avermectin }\end{array}$ & $\begin{array}{c}153.4 \pm \\
6.66^{* *}\end{array}$ & 125.53 & $\begin{array}{c}73 \pm \\
4.57^{\mathrm{ns}}\end{array}$ & 112.31 & $\begin{array}{l}3.14 \pm \\
0.07^{\mathrm{ns}}\end{array}$ & 109.03 & $\begin{array}{c}65.74 \pm \\
0.70^{* * *}\end{array}$ & 137.24 & $\begin{array}{c}25.32 \pm \\
1.82^{*}\end{array}$ & 131.87 \\
\hline Control & $\begin{array}{c}122.2 \pm \\
1.56\end{array}$ & - & $\begin{array}{l}65 \pm \\
3.16\end{array}$ & - & $\begin{array}{c}2.88 \pm \\
0.09\end{array}$ & - & $\begin{array}{c}47.9 \pm \\
1.4\end{array}$ & - & $\begin{array}{c}19.2 \pm \\
0.2\end{array}$ & - \\
\hline
\end{tabular}

\section{Effect on kidney function parameters}

Uric acid and creatinine are useful in early deduction of nephrotoxicity induced by exogenous compounds. These parameters are used as index of renal damage in living organisms by Coles (1986). Elevation of uric acid and creatinine concentration in serum of treated male albino rats may be attributed to reduction in glomerular filtration in the kidney and also reflect dysfunction of the kidney tubules (Hayes, 1989, Walmsley and White, 1994).

Results in Table (4) illustrated that, methylamine avermectin leads to a non significant increase in the activity of creatinine, but the activity of urea increased significantly in serum of treated rats, as compared with the control group. The obtained results agreed with those obtained by Arise and Malomo (2009) they found ivermectin led to significant increase in serum urea, creatinine concentrations, these observations may be suggestive of deranged membrane structures and functions. 
Abed El-Hamid and Refaie (2009) found that avermectin toxicity resulted in significant increase in urea. Eissa and Zidan (2009) they found that Vertimec increased uric acid and creatinine concentrations in serum of treated rats in a dose dependent manner.

Table 4. Serum Creatinine and Urea activities $(\mathrm{mg} / \mathrm{dl})$ of male albino rats as aresult of methylamine avermectin treatment.

\begin{tabular}{|c|c|c|c|c|}
\hline \multirow{2}{*}{ Treatment } & \multicolumn{2}{|c|}{ Creatinine } & \multicolumn{2}{|c|}{ Urea } \\
\hline & activity & $\begin{array}{c}\text { \% of } \\
\text { change }\end{array}$ & Activity & $\begin{array}{c}\text { \% of } \\
\text { change }\end{array}$ \\
\hline $\begin{array}{l}1 / 10 \text { LD }_{50} \\
\text { methylamine } \\
\text { avermectin }\end{array}$ & \multicolumn{4}{|c|}{ All tested rats died after 10 days of the experiment duration. } \\
\hline $\begin{array}{c}1 / 40 \text { LD }_{50} \\
\text { methylamine } \\
\text { avermectin }\end{array}$ & $0.88 \pm 0.06^{\mathrm{ns}}$ & 18.92 & $23.16 \pm 2.36^{*}$ & 42.96 \\
\hline Control & $0.74 \pm 0.03$ & - & $16.2 \pm 0.37$ & - \\
\hline
\end{tabular}

\section{Effect on testes function parameters}

Testosterone is the most important androgen secreted into the blood by the Leydig cells of the testes in males. The changes in the rate of inactivation and elimination of testosterone, due to chemical exposure, can alter the levels of circulating testosterone and thereby disrupt steroid hormone homeostasis. Wilson \& LeBlanc, (2000).

Data in Table (5) illustrated that, methylamine avermectin decrease significantly the activity of testesterone in serum of treated rats, as compared with the control group. These results were in harmony with those obtained by Elbetieha and Da'as (2003) who found the serum level of testosterone was significantly reduced when adult male rats were exposed to tap water containing $0,571,857$, or 1714 ppm abamectin for 6 weeks. 
Table 5. Serum testesterone activity $(\mathrm{ng} / \mathrm{ml})$ of male albino rats as aresult of methylamine avermectin treatment.

\begin{tabular}{|c|c|c|}
\hline \multirow{2}{*}{ Treatment } & \multicolumn{2}{|c|}{ Testesterone } \\
\cline { 2 - 3 } & activity & \multicolumn{2}{|c|}{$\%$ of change } \\
\hline \multirow{2}{*}{$\mathbf{1} \mathbf{1 0}$ LD $_{\mathbf{5 0}}$ methylamine avermectin } & All tested rats died after 10 days of the experiment duration. \\
\hline $\mathbf{1 / 4 0}$ LD $_{\mathbf{5 0}}$ methylamine avermectin & $24.2 \pm 1.53^{* * *}$ & 73.98 \\
\hline Control & $93 \pm 8.60$ & - \\
\hline
\end{tabular}

\section{REFERENCES}

1. Abdel Rahman, E. F., A. M. Azab, M. M. Ali, G. A. Morsi and A. Ahmed Mahasen. 2008. Comparative toxicity of three novel biotic compounds, Spinosad, Pyridalyl and Radical in relative to a conventional insecticide, Lannate against the field and laboratory strain of the second and fourth instar larvae of cotton leafworm, Spodoptera littoralis (Boisd.)., Egypt. J. Agric. Res., 87 (2) : 433-453.

2. Abed El-Hamid, S. R. and A. A. Refaie. 2009. Ameliorative effect of Silybum marianum extract against avermectin induced toxicity In adult male rats. jasmr, 4 (1) : 25-31.

3. Amin, A. A. A., M. Gergis and M. El-Naggar. 2001. Alternative infield refuge strategies for controlling certain cotton key pests in middle Egypt. The ESA 2001 Annual Meeting - December 2001: An Entomological Odyssey of ESA, San Diego, CA.

4. Arise, R. O. and S. O. Malomo. 2009. Effects of ivermectin and albendazole on some liver and kidney function indices in rats. African J. Biochem. Research. 3 (5) : 190-197.

5. Balistreri, W.F. and L. M. Shaw. 1987. Liver Function. In: (Fundamentals of Clinical Chemistry. Tietz, N.W. ed). 3rd ed., W.B. Saunders Company, Philadelphia, pp: 729.

6. Burg, R. W., B. M. Miller, E. E. Baker, J. Birnbaum, S. A. Currie, R. Hartman, Y. L. Kong, R. L. Monaghan, G. Olson, I. Putter, J. B. Tunac, H. Wallick, E. O. Stapley, R. Oiwa and S. Omura. 1979. Avermectins, a new family of potent anthelminthic agents producing organisms and fermentations. Antimicrob. Agents Chemothe., $15: 361-367$.

7. Coles, E. H. 1986. Veterinary Clinical Pathology. 4th ed., W. B. Saunders Co, Philadelphia.

8. Dahi , H. F., Y. A. El-Sayed, N. M. El-Barkey and M .F. Abd-El Aziz. 2009. Toxicological and biochemical studies of Methylamine Avermactin, a new type of 
bioinsecticide against the cotton leafworm, Spodoptera littoralis (Biosd.). Egypt. Acad. J. biolog. Sci., 2 (1) : 103- 116.

9. Eissa, F. I. and N. A. Zidan. 2009. Haematological, Biochemical and Histopathological Alterations Induced by Abamectin and Bacillus thuringiensis in Male Albino Rats. Australian J. Basic and Applied Sci., 3 (3) : 2497-2505.

10. Elbetieha, A. and S. I. Da'as. 2003. Assessment of antifertility activities of abamectin pesticide in male rats. Ecotoxicology and Environmental Safety 55, 307-313.

11. El-Defrawi, M. E., A. Toppozada, N. Mansour and M. Zeid. 1964. Toxicological studies on the Egyptian cotton leafworm, Prodenia littura (L.). I. Susceptibility of different larval instars of Prodenia to insecticides. J. Econ. Entomol., 57 : 591-593.

12. Finney, D. J. 1971. Probit analysis. Cambridge univ., London pp 333.

13. Fritz, L. C., C. C. Wang and A. Gorio. 1979. Avermectin B a irreversibly blocks postsynaptic potentials at the lobster neuromuscular junction by reducing muscle membrane resistance. Proc. Natl. Acad. Sci. U.S.A. 76 : 2062-2066.

14. Hayes, A. W. 1989. Principles and methods of toxicology. 2nd ed., Raven Pres s, New York.

15. Hsu, Dur-Zong, Hsu, Ching-Hung, Huang, Bu-Miin, Liu, MingYie. 2001. Abamectin effects on aspartate aminotransferase and nitric oxide in rats. J. Toxicol. 165: 189-193.

16. Klaassen C. D. and D. L. Eaton. 1991. Principles of toxicology. In: Amdur, M.O., Doull, J., Klaassen, C.D. (Eds .), Toxicology, 4th ed. McGraw-Hill, New York, pp : 12.

17. Peng, D., S. Chen, L. Ruan , L. Li. , Z.Yu and M. Sun. 2007. Safety assessment of transgenic Bacillus thuringiensis with VIP insecticidal protein gene by feeding studies . Food Chem Toxicol, 45 : 1179-1185.

18. Plaa, G. L. and W. R Hewitt. 1982. Detection and evaluation of chemically induced liver injury. In: Hayes,W. (Ed.), Principles and Methods of Toxicology. Raven Press, New York, pp : 407.

19. Soliman, Hanan A., M. B. Ahmed, A. A. El-Kashorey and E. M. Moawad. 2009. Effect of Ivermectin on Liver Function and Lipid Peroxidation. Egyptian Journal of Natural Toxins, 6 (1) : 97-107.

20. Walmsley, R. N. and G. H. White. 1994. A Guide to Diagnostic Clinical Chemistry. 3rd ed., Blackwell Scientific Publication, London.

21. Wilson, V. S. and G. A. LeBlanc. 2000. The contribution of hepatic inactivation of testosterone to the lowering of serum testosterone levels by ketoconazole. Toxicol. Sci., 54 : 128-37. 


\section{دراسة تاثيرالميثيل أمين أفيرميكتين كركب حيوى جديد على دوده ورق القطن (اسبودويترا ليتوراليز) و ذكورالفئران البضاء}

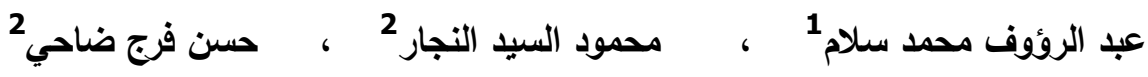

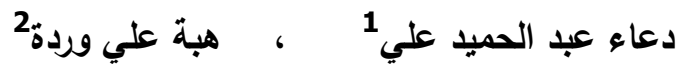

$$
\begin{aligned}
& \text { 1. جامعة المنصورة - كلية العلوم - قسم علم الحبوان. } \\
& \text { 2. معهُ بحوث وقاية النبات - مركز البحوث الزراعية - الدقي - الجيزة. }
\end{aligned}
$$

يعتبر الميثيل أمين أفيرميكتين ( الراديكال ) من المركبات الحيوية الجديدة كنواتج ايض ثانوية

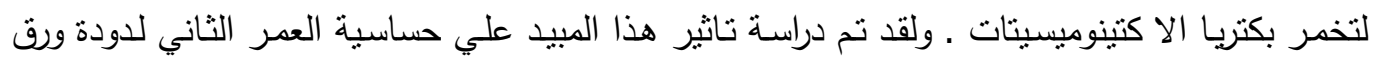

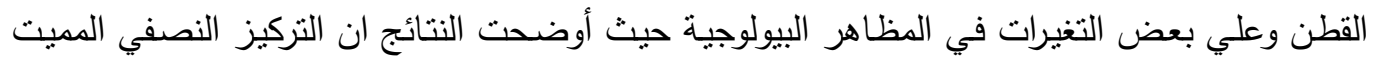

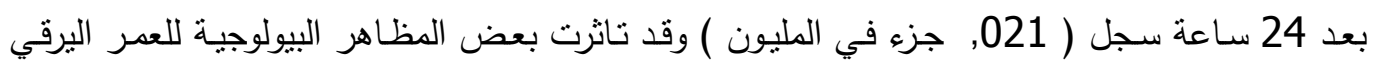

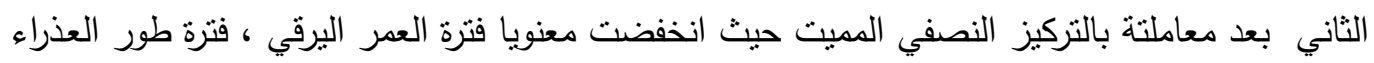

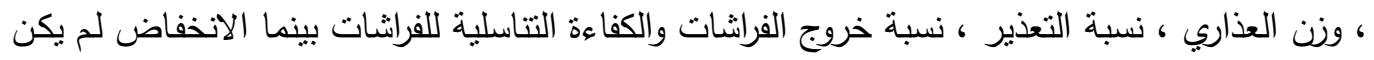

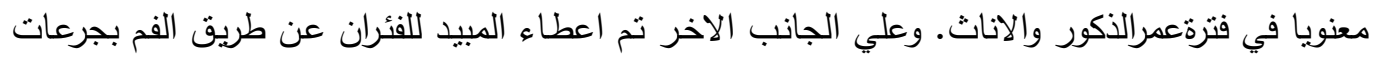

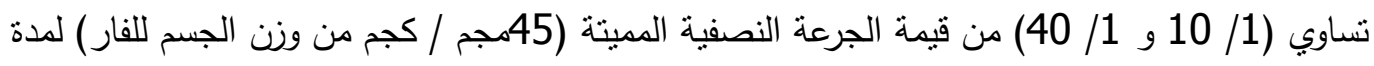
واحد وعشرون يوم (يوم بعد يوم) حيث اظهرت النتائج البيوكيمائية مدي تاثير الميثيل أمين أفيرميكتين علي وظائف الكبد والكلي والخصية للفئران المعاملة . 